\title{
Effects of CB2 and TRPV1 receptors' stimulation in pediatric acute T-Iymphoblastic leukemia
}

\author{
Francesca Punzo ${ }^{1,2}$, Iolanda Manzoㄹ, Chiara Tortora², Elvira Pota ${ }^{1}$, Velia D' \\ Angelo ${ }^{1}$, Giulia Bellini ${ }^{2}$, Alessandra Di Paola ${ }^{1}$, Federica Verace ${ }^{1}$, Fiorina Casale $^{1}$ \\ and Francesca Rossi ${ }^{1}$ \\ 1Department of Women, Child and General and Specialist Surgery, University of Campania "Luigi Vanvitelli", Naples 80138, \\ Italy \\ ${ }^{2}$ Department of Experimental Medicine, Division of Pharmacology "Leonardo Donatelli", University of Campania "Luigi \\ Vanvitelli", Naples 80138, Italy \\ Correspondence to: Francesca Rossi, email: francesca.rossi@unicampania.it
}

Keywords: oncogene; MYB; SKl; transcriptional regulation; acute myeloid leukemia

Received: August 24, $2017 \quad$ Accepted: March 21, $2018 \quad$ Published: April 20, 2018

Copyright: Punzo et al. This is an open-access article distributed under the terms of the Creative Commons Attribution License 3.0 (CC BY 3.0), which permits unrestricted use, distribution, and reproduction in any medium, provided the original author and source are credited.

\section{ABSTRACT}

T-Acute Lymphoblastic Leukemia (T-ALL) is less frequent than B-ALL, but it has poorer outcome. For this reason new therapeutic approaches are needed to treat this malignancy.

The Endocannabinoid/Endovanilloid (EC/EV) system has been proposed as possible target to treat several malignancies, including lymphoblastic diseases. The EC/EV system is composed of two G-Protein Coupled Receptors (CB1 and CB2), the Transient Potential Vanilloid 1 (TRPV1) channel, their endogenous and exogenous ligands and enzymes. CB1 is expressed mainly in central nervous system while CB2 predominantly on immune and peripheral cells, therefore we chose to selectively stimulate CB2 and TRPV1.

We treated T-ALL lymphoblasts derived from 4 patients and Jurkat cells with a selective agonist at CB2 receptor: JWH-133 [100 $\mathrm{nM}$ ] and an agonist at TRPV1 calcium channel: RTX [5 uM] at 6, 12 and 24 hours. We analyzed the effect on apoptosis and Cell Cycle Progression by a cytofluorimetric assays and evaluated the expression level of several target genes (Caspase 3, Bax, Bcl-2, AKT, ERK, PTEN, Notch-1, CDK2, p53) involved in cell survival and apoptosis, by Real-Time PCR and Western Blotting.

We observed a pro-apoptotic, anti-proliferative effect of these compounds in both primary lymphoblasts obtained from patients with T-ALL and in Jurkat cell line. Our results show that both CB2 stimulation and TRPV1 activation, can increase the apoptosis in vitro, interfere with cell cycle progression and reduce cell proliferation, indicating that a new therapeutic approach to T-cell ALL might be possible by modulating CB2 and TRPV1 receptors.

\section{INTRODUCTION}

Leukemias encompass $30 \%$ of all pediatric cancers, and acute lymphoblastic leukemia (ALL) is the most common leukemia in the pediatric population; it comprises $75 \%$ of all pediatric leukemia cases $[1,2]$. Childhood ALL incidence is 3-4 cases per 100,000 in under 15-year-old children and it usually occurs when the child is between
2 and 5 years old. ALL is an heterogeneous disease: subtypes differ with regard to biological, cellular and molecular characteristics, response to therapy and risk of relapse, and are associated with different outcomes [3-6]. T-ALL constitutes approximately $15 \%$ of pediatric ALL but shows a poorer outcome compared to B-ALL [7]. In fact, children with T-ALL tend to experience more induction failures and extramedullary relapses 
than their B-ALL counterparts and frequently present with unfavorable clinical features, such as male gender, older age, high white blood cell count (WBC), bulky extramedullary disease, and CNS involvement $[8,9]$. In spite of improved survival rates obtained with riskadjusted therapy, $25 \%$ of T-ALL patients have little or no expectancy of cure. Hence, identification of new prognostic markers and development of new therapeutic targets remain a critical task to help children with T-ALL. In the last decade, several studies proposed cannabinoids as antineoplastic drugs to treat malignancies of the immune system [10-16]. "Cannabinoid" is the collective term for a group of chemical compounds that derive from the Cannabis plant, like as synthetic or endogenous (endocannabinoids) analogues, and that interact with specific receptors: cannabinoid receptor type 1 (CB1), cannabinoid receptor type 2 (CB2), transient receptor potential vanilloid type 1 (TRPV1). Generally, CB1 signaling mediates neuromodulatory activities (CB1 receptors are expressed at high levels in CNS), and CB2 signaling mostly mediates immunomodulatory activities of these compounds (CB2 receptors are primarily expressed on immune and peripheral cells) [17, 18]. TRPV1 has been described as an additional receptor target for several cannabinoids such as Anandamide which is capable of binding both Cannabinoids and Vanilloid receptors $[19,20]$. When TRPV1 channel proteins are activated, they induce massive calcium intake in the cell [21]. Intracellular calcium overload mediate cell apoptosis through different mechanism interfering with cell energy production and metabolism, therefore also drugs acting on the TRPV receptors, potentially can act as target to reduce cell proliferation and survival in cancer $[22,23]$. Evidences on the cross-talk between $\mathrm{CB} 2$ receptors and TRPV1 channels have been demonstrated [24-27]. Cannabinoid receptors have been shown to modulate several signaling pathways involved in the control of cell proliferation and survival [28-31]. Moreover we have recently demonstrated an anti-proliferative, pro-apoptotic and anti-invasive effect induced by EC/EV compounds in human osteosarcoma [32].

The ability to regulate the apoptotic process upon their activation, the selective presence of the CB2 and the TRPV1 on immune system cells, and their ability not to induce psychotropic effects, suggest these receptors as new possible pharmacological targets for those diseases affecting the immune system cells. Based on these evidences, we investigated for the first time the expression of CB2 and TRPV1 receptors in primary lymphoblast cultures deriving from 4 T-ALL patients and in Jurkat cell line. We evaluated the effects of two agonists of the EC/EV system (RTX selective on TRPV1 receptors and JWH-133 selective over CB2 receptors) at different times of exposure in these cells, analyzing the effects on cell survival, cell cycle progression and apoptosis. We observed an anti-proliferative, pro-apoptotic effect induced by these EC/EV compounds in T-ALL patients and Jurkat cells.

\section{RESULTS}

\section{Jurkat and T-ALL cells express EC/EV system}

We first evaluated the expression of CB2 and TRPV1 in untreated Jurkat cell line and primary patient's lymphoblasts, to verify the presence of the receptors we were going to stimulate. The result demonstrated the presence of mature mRNA for CB2 and TRPV1 receptors (Supplementary Figure 1).

\section{Effect of EC/EV compounds in Jurkat and T-ALL cells on Apoptosis}

We observed an effect on apoptosis in both patients' and Jurkat cells after Vanilloid and Cannabinoid stimulation with selective agonists (RTX and JWH-133) (Table 1 and Supplementary Figure 2). Both JWH-133 [100 nM] and RTX [5 $\mathrm{uM}]$ increased apoptosis in all samples and at all time points, and the difference at $6 \mathrm{~h}$ and $12 \mathrm{~h}$ was statistically significant in both cell types, while at $24 \mathrm{~h}$ it remained statistically relevant only in Patients' cells, compared to the non-treated cell line. To evaluate the possible molecular mechanism through which $\mathrm{EC} / \mathrm{EV}$ drugs act on apoptosis, we analyzed the expression levels of Caspase-3 after JWH-133 [100 nM] (Figure 1A) and RTX [5 $\mu \mathrm{M}]$ (Figure 1B) treatments by Real Time PCR and Western Blotting (Figure 1C, 1D). Both compounds (JWH-133 and RTX) induced a significant increase of Caspase- 3 expression in T-ALL patients and Jurkat cells (Figure 1A, 1B) at mRNA level, where we evaluated the Caspase 3 mRNA and also by Western Blot where the Pro-Caspase 3 levels were examined (Figure 1C, 1D). Moreover we evaluated also Bax/Bcl-2 ratio (only in Jurkat cells) in order to add more evidences on the effect of these compounds on Apoptosis. The Ratio is increased in a statistically significant level following administration of both JWH-133 $[100 \mathrm{nM}]$ and RTX [5 $\mu \mathrm{M}]$ (Figure 2A, 2B).

\section{Effects of EC/EV compounds in Jurkat and T-ALL cells on cell proliferation}

To evaluate the possible molecular mechanisms through which EC/EV selective agonists act on cell proliferation, we analysed the expression levels of a series of genes known to be involved in cell proliferation such as AKT (or PKB, Protein Kinase B), ERK (MitogenActivated-Protein Kinase 1), PTEN (Phosphatase and Tensin Homolog), NOTCH-1 and Tumor Protein p53.

Total AKT levels measured by Real Time PCR are reduced in Jurkat and T-ALL patient's lymphoblasts by both compounds (JWH-133 and RTX) (Figure 3A, 3B). The phosphorylated form of AKT was remarkably 


\section{Caspase 3}

A JWH-133 [100 nM]

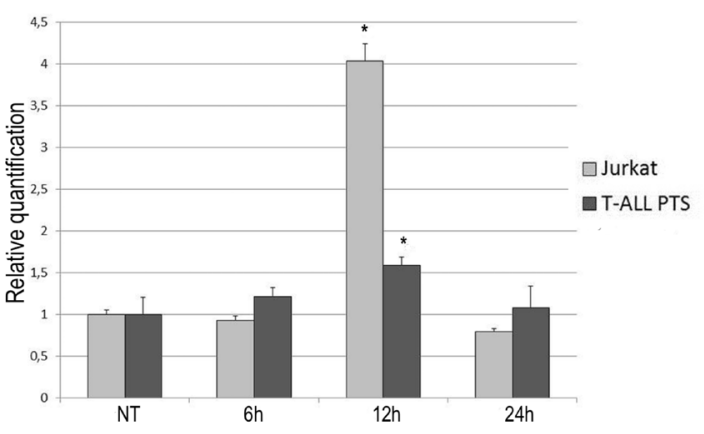

B

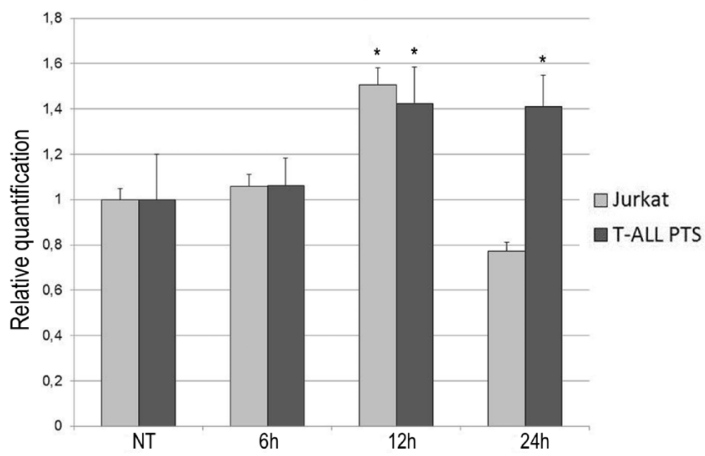

pro-Caspase 3

C
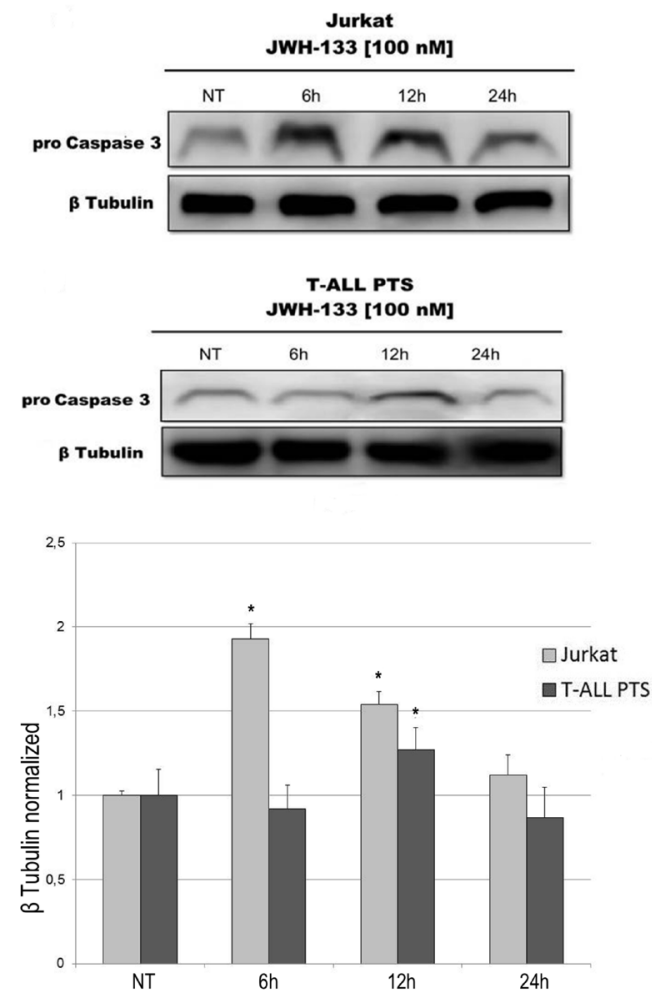

D
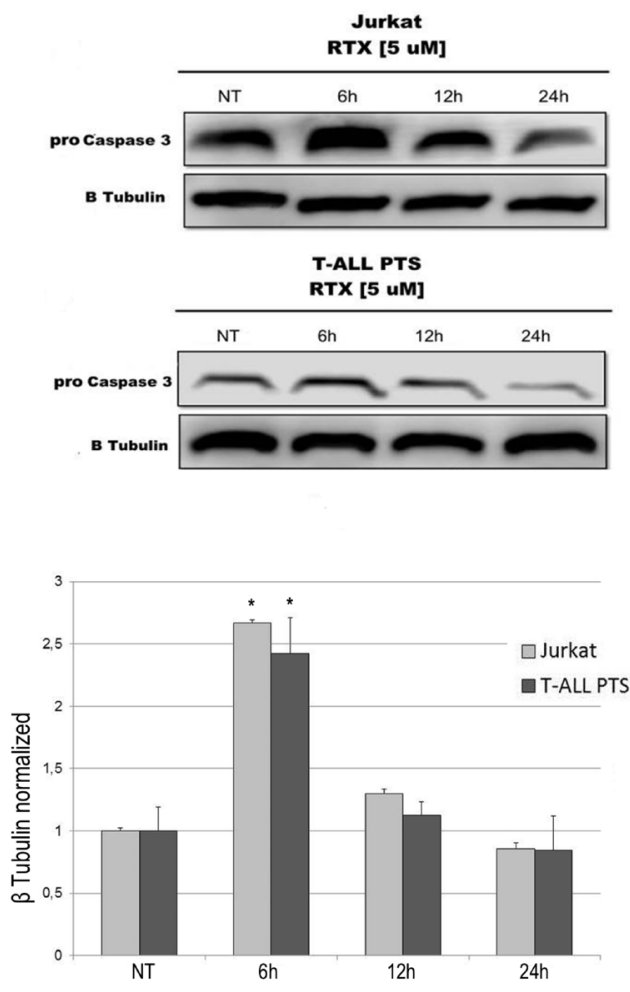

Figure 1: Effects of JWH-133 and RTX treatments on Caspase-3 mRNA expression levels and on Pro-Caspase 3 protein expression levels. Caspase- $3 \mathrm{mRNA}$ expression levels in Jurkat cell line and in T-ALL patients' lymphoblasts derived from 4 patients were determined by Q-PCR after JWH-133 [100 nM] treatment (A) and RTX [5 uM] (B) treatments at $6 \mathrm{~h}, 12 \mathrm{~h}$ and $24 \mathrm{~h}$ of exposure. Results were normalized for the housekeeping gene $\beta$-actin and were showed as mean $\pm \mathrm{SD}$ of three independent experiments in Jurkat cells (performed in technical triplicate), and as mean $\pm \mathrm{SD}$ of four single experiments on each one of the 4 patients (performed in technical triplicate). A $t$-test has been used to evaluate statistical differences in Caspase-3 mRNA expression among groups. "indicates $p \leq$ 0.05 compared to the untreated control (NT). Pro-Caspase 3 protein expression levels in Jurkat cell line and in T-ALL patients' lymphoblasts, were determined by Western Blot, starting from $15 \mu \mathrm{g}$ of total lysates after JWH-133 [100 nM] (C) and RTX [5 uM] (D) treatments at $6 \mathrm{~h}, 12 \mathrm{~h}$ and $24 \mathrm{~h}$ of exposure. The images show the most representative blots. The proteins were detected using Image Studio Digit software and the intensity ratios of immunoblots compared to the one of the untreated control, taken as 1 (arbitrary unit), were quantified after normalizing with respective loading controls for the housekeeping protein $\beta$-tubulin. The graphs show the relative quantification for pro-Caspase-3, represented as mean \pm SD of two independent experiments for Jurkat cells and as mean \pm SD of four single experiments performed on each one of the 4 patients. A $t$-test has been used to evaluate the statistical differences in protein expression levels. " indicates $p \leq 0.05$ compared to the untreated control (NT). 
Table 1: Percentage of total apoptotic cells in Jurkat cell line and in T-ALL patients' lymphoblasts after JWH-133 and RTX treatments

\begin{tabular}{lccc}
\hline Jurkat & $\mathbf{6 ~ h ~ ( \% )}$ & $\mathbf{1 2} \mathbf{h}(\mathbf{\%})$ & $\mathbf{2 4} \mathbf{h}(\mathbf{\%})$ \\
\hline NT & $22.8 \pm 2.3$ & $15.1 \pm 2.4$ & $26.5 \pm 2.7$ \\
JWH-133 [100 nM] & $46.9 \pm 2.3^{*}$ & $28.5 \pm 2.4^{*}$ & $33.3 \pm 2.5^{*}$ \\
RTX [5 $\boldsymbol{\mu M}]$ & $52.3 \pm 2.2^{*}$ & $42.5 \pm 2.4^{*}$ & $30.8 \pm 2.7$ \\
\hline ALL T PTS & $\mathbf{6 ~ h ~ ( \% )}$ & $\mathbf{1 2} \mathbf{h ~ ( \% )}$ & $\mathbf{2 4} \mathbf{h}(\mathbf{\%})$ \\
\hline NT & $13.8 \pm 4.1$ & $20.9 \pm 4.9$ & $14.4 \pm 4.8$ \\
JWH-133 [100 nM] & $32.9 \pm 5.4^{*}$ & $30.4 \pm 3.1^{*}$ & $26.8 \pm 4.9^{*}$ \\
RTX [5 $\boldsymbol{\mu M ]}$ & $30.2 \pm 4.2^{*}$ & $32.5 \pm 4.7^{*}$ & $26.5 \pm 4.8^{*}$ \\
\hline
\end{tabular}

Analysis of cell apoptosis by Annexin-V and PI double-stained in Jurkat cells line and T-ALL patients' lymphoblasts derived from 4 patients induced by JWH-133 [100 nM] and RTX [5 uM], after $6 \mathrm{~h}, 12 \mathrm{~h}$ and $24 \mathrm{~h}$ of exposure. The results are presented as the mean percentage $\pm \mathrm{SD}$ of three independent experiments for Jurkat cells and as mean percentage \pm SD of 4 single experiments on each one of the 4 patients. The results were analyzed by one-way analysis of variance (ANOVA). *indicates $p \leq 0.05$ compared to the untreated control (NT).

reduced, in Jurkat cells and in T-ALL patients' cells, $6 \mathrm{~h}$ and $12 \mathrm{~h}$ after JWH-133 [100 nM] (Figure 3C) and RTX [5 $\mu \mathrm{M}$ ] (Figure 3D) exposure as shown by Western Blot analysis. To quantify the reduction of the active form of Akt we calculated the pAkt/Akt ratio as shown in the graphs of Figure 3C, 3D. Moreover, JWH-133 [100 nM] treatment results in a significant decrease of ERK mRNA levels at all time points $(6 \mathrm{~h}, 12 \mathrm{~h}$ and $24 \mathrm{~h})$ in Jurkat cells, while in patients the decrease is not statistically significant (Figure 4A). RTX [5 $\mu \mathrm{M}]$ treatment induced a significant decrease of ERK mRNA expression in Jurkat cell lines after $6 \mathrm{~h}$ and $12 \mathrm{~h}$ of exposure as compared to respective control, while in patients' cells there are not significant changes (Figure 4B) whereas when analyzing the active form of the protein by Western Blot, pERK resulted reduced in a statistically significant manner, in both Jurkat and T-ALL patient's cells by both treatments (JWH-133 and RTX) (Figure 4C, 4D).

The expression levels of PTEN, NOTCH-1 and p53 after JWH-133 [100 nM] and RTX [5 $\mu \mathrm{M}]$ treatments, was evaluated by Real Time PCR (Figure 5). JWH-133 treatment induced a significant increase of PTEN mRNA levels in the Jurkat cells while in patients the increase is still visible but the variation is not statistically significant (Figure 5A). On the other hand RTX induced a significant increase of PTEN mRNA levels only in T-ALL patients cells whereas in Jurkat cell line we did not observed any effect (Figure 5B). Expression level of NOTCH-1 decreases significantly only after treatment with JWH-133 in Jurkat and with RTX in T-ALL Patients (Figure 5C, 5D) while mRNA levels of $\mathrm{p} 53$ resulted dramatically increased by JWH$133[100 \mathrm{nM}]$ and RTX $[5 \mu \mathrm{M}]$ treatments in Jurkat cells. In T-ALL patients p53 mRNA levels displayed a statistically significant increase only after Vanilloid stimulation (Figure 5E, 5F).

\section{Effect of EC/EV compounds in Jurkat and T-ALL cells on cell cycle progression}

To evaluate the possible role of EC/EV drugs on cell cycle progression we performed a specific assay on the Muse Cell Analyser. Cells were incubated for 6 h, 12 h, $24 \mathrm{~h}$ and $48 \mathrm{~h}$ after exposure to JWH-133 [100 nM], RTX $[5 \mu \mathrm{M}]$ or untreated. The Muse cell Analyser automatically displayed the percentage of cells in $\mathrm{G} 0 / \mathrm{G} 1$, $\mathrm{S}$ and G2/M phases of the cell cycle (Table 2). In Jurkat cells, while already at $12 \mathrm{~h}$ there is a marked reduction of cells in S phase, at $24 \mathrm{~h}$ we observe an increase of cells in G0/G1. This increase is still present when performing the analysis at $48 \mathrm{~h}$, demonstrating clearly that those cells did not proceed to the next phases of the cell cycle (Table 2A) which indicates an impairment in cell cycle progression caused by EC/EV agonists. In T-ALL patients cells (Table 2B) the results show the same pattern but are not statistically relevant, probably due to the samples heterogeneity or slower cell replication time. To confirm what observed in the Cell Cycle Assay we evaluated the expression levels of CDK2 both at mRNA levels and the phosphorylated protein. JWH-133 [100 nM] and RTX [5 $\mu \mathrm{M}]$ reduced the expression of this important cycline for cell cycle progression, in a statistically significant manner, even if at different time points ( $6 \mathrm{~h}$ for Jurkat and $12 \mathrm{~h}$ for T-ALL patients cells) (Figure 6A, 6B). By Western Blot we analysed the expression of the active form of this protein (phosphorylated) and confirmed the result obtained on mRNA (Figure 6C, 6D).

\section{DISCUSSION}

T-cell Acute Lymphoblastic Leukemia (T-ALL) represents about $10-15 \%$ of pediatric ALL cases but it has a worse outcome compared to B-lineage ALL, especially 
A
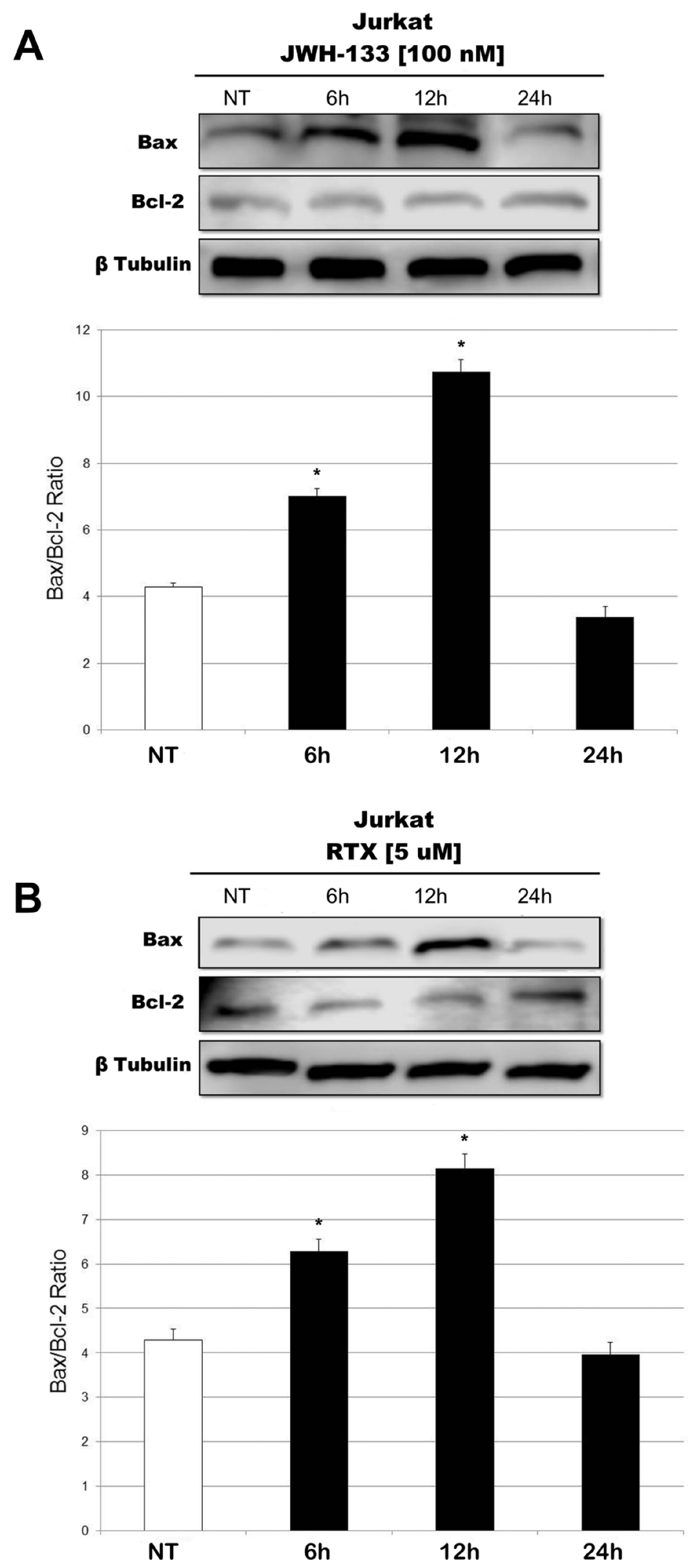

Figure 2: Effects of JWH-133 and RTX treatments on Bax/Bcl-2 ratio, in Jurkat cell line. Bax and Bcl-2 protein expression levels in Jurkat cell line, determined by Western Blot, starting from $15 \mu \mathrm{g}$ of total lysates after JWH-133 [100 nM] (A) and RTX [5 uM] (B) treatments at $6 \mathrm{~h}, 12 \mathrm{~h}$ and $24 \mathrm{~h}$ of exposure. The results were normalized for the housekeeping protein $\beta$-tubulin. The most representative images are displayed. The graphs represent the ratio between Bax and Bcl-2 as the mean and \pm S.D. from two experiments. A $t$-test has been used to evaluate the statistical differences in protein expression levels. ${ }^{*}$ indicates $p \leq 0.05$ compared to the untreated control (NT). 
when the patient presents poor response to prednisone therapy $[5,7,8]$. For this reason new therapeutic approaches are needed.

Cannabinoids have been shown to induce apoptosis in human leukemia and lymphoma cell lines via CB2, the cannabinoid receptor normally expressed in the immune system [14-16, 33, 34]. TRPV1 has been found to be functionally expressed in $\mathrm{CD}^{+} \mathrm{T}$ cells and it contributes to $\mathrm{T}$ cell receptor (TCR)-induced $\mathrm{Ca}^{2+}$ channel influx [35].

In the present study we analyzed the therapeutic potential of two EC/EV drugs, JWH-133 (a potent CB2 selective agonist) and RTX (an analog of capsaicin, a vanilloid agonist), in primary cell cultures obtained from 4 patients affected with T-ALL and in Jurkat cell line.

The treatments were carried out at different incubation times, but the most significant effects were observed after 6 hours of drug administration, especially in the Jurkat cell line and mostly after 12 hours in T-ALL patients' primary cell cultures, since these cells duplicate much slower than Jurkat. Many signaling pathways involved in apoptosis, cell cycle progression and proliferation are usually dysregulated in cancer cells [6]. In this study, we demonstrated that stimulation of EC/EV system induces apoptosis in both cultured T-ALL patient cells and in Jurkat cells. Firstly we demonstrated an increase in apoptosis in the cells studied. Moreover considering the central role of Caspase- 3 in executing apoptosis [36], and the observation that several cancer cells exhibit altered Caspases-3 expression [37, 38], we also examined the expression levels of Caspase- 3 in our samples, which resulted increased after $\mathrm{EC} / \mathrm{EV}$ stimulation. To better understand the biological mechanism through which these compounds could increase apoptosis we also evaluated the pro-apoptotic protein Bax and the anti-apoptotic $\mathrm{Bcl} 2$ demonstrating an increased ratio which indicates a tendency to induce the apoptotic cascade.

On the other hand we investigated the effect of JWH-133 and RTX on the cell survival pathways. It is well established that Mitogen-Activated Protein Kinase (MAPK) cascades, especially those involving extracellular signal-regulated kinase (Erk) 1/2 activated by MAPK/ Erk kinase (MEK) 1/2 dual-specificity protein kinases, promote cancer cell survival $[39,40]$. The constitutive activation of PI3K/Akt signaling pathway is a very common event in T-ALL and is critical for leukemic cell viability. PI3K/Akt pathway hyperactivation appears to result mainly from post-translational inactivation of the Phosphatase and Tensin homolog (PTEN) protein, which is the main negative regulator of PI3K/Akt pathway [39, 41-43]. The activation of PI3K/Akt is also associated with Notch1 activation. Notch 1 transcriptionally represses PTEN. A significant subset of newly diagnosed T-ALL patient samples are known to present inactivating PTEN gene mutations. These mutations may collaborate with PTEN post-translational inactivation to maximize its functional deficiency, thus contributing to increase PI3K/ Akt activation and finally to leukemia resistance to chemotherapy [44-46]. In our study we demonstrated a downregulation of ERK and AKT especially at protein level in their active forms and also a decrease of Notch-1 mRNA level, together with an overexpression of PTEN. Studies revealed that down regulation of Notch-1 could induce $\mathrm{G}(0) / \mathrm{G}(1)$ cell cycle arrest and apoptosis. The effects might be mediated by regulating the Cycline dependent Kinases 2 (CDK2) expression and the Akt signaling $[47,48]$. For this reason we performed also a Cell Cycle Progression Assay and examined the expression levels CDK2 at mRNA and protein level.

In tumors, cell cycle dysregulation caused an abnormal cell growth. More than $90 \%$ of human cancers have been found with the alterations of cyclin-dependent kinases (CDKs) which were most related with G1 phase [49].The transition from $\mathrm{G} 0 / \mathrm{G} 1$ to $\mathrm{S}$ phase is responsible for initiation and completion of DNA replication. In the present study, in Jurkat cells we observed first a reduction of cells in $\mathrm{S}$ phase and subsequently a significant accumulation in G0/G1-phase compared with cancerous untreated cells. To further investigate the molecular basis by which CB2 and TRPV1 agonists inhibited the G0/G1 transition in T-ALL, we also analyzed the expression of CDK2 mRNA and the active form of the protein $\mathrm{pCDK} 2$. This protein has been found downregulated by EC/EV ligands which confirm that RTX and JWH-133 might trigger the progression of cell cycle in T-ALL and may result in the blockage of cell division, cell death, and/or apoptosis.

Moreover, in our study we demonstrated a significant upregulation of p53 by RTX and JWH-133. P53 is a tumor suppressor that is lost or inactivated in the majority of tumors [50]. P53 protein is a tumor suppressor that serves as a genomic guardian to maintain a dynamic balance between cell growth and cell arrest in response to genomic stress [51]. Mutations and/or deletions in p53 predict a poorer outcome in T-ALL patients $[52,53]$. The activation of P53 can be beneficial for cancer treatment outcome to contribute to more efficient tumor cell killing by restoring p53 function to the level of a normal tissue in those patients who do not suffer from a genetic mutation on that gene.

In conclusion we demonstrated a downregulation of genes involved in cell cycle progression and proliferation, and upregulation of genes involved in apoptosis together with cell cycle arrest in Jurkat cells, following administration of selective agonist of CB2 and TRPV1 receptors.

Taken together, these data show an important switch toward the programmed cell death in the cells studied following EC/EV stimulation. Other studies have been conducted using cannabinoids in Jurkat cell line but we used also patients' derived lymphoblasts and in prospective of a clinical application, we chose two drugs selectively acting on TRPV1 and CB2 receptors and so probably without psychotropic effects. Further studies, combining the compounds used in this study with current conventional T-ALL therapy, and in-vivo studies on animal 
AKT

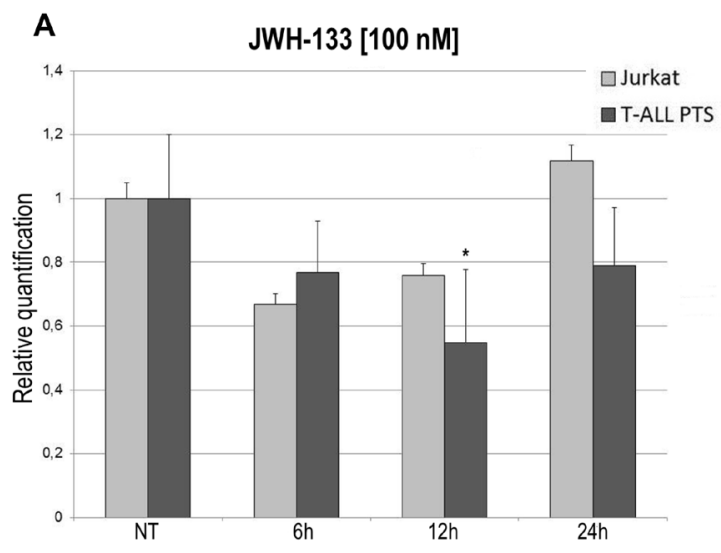

B
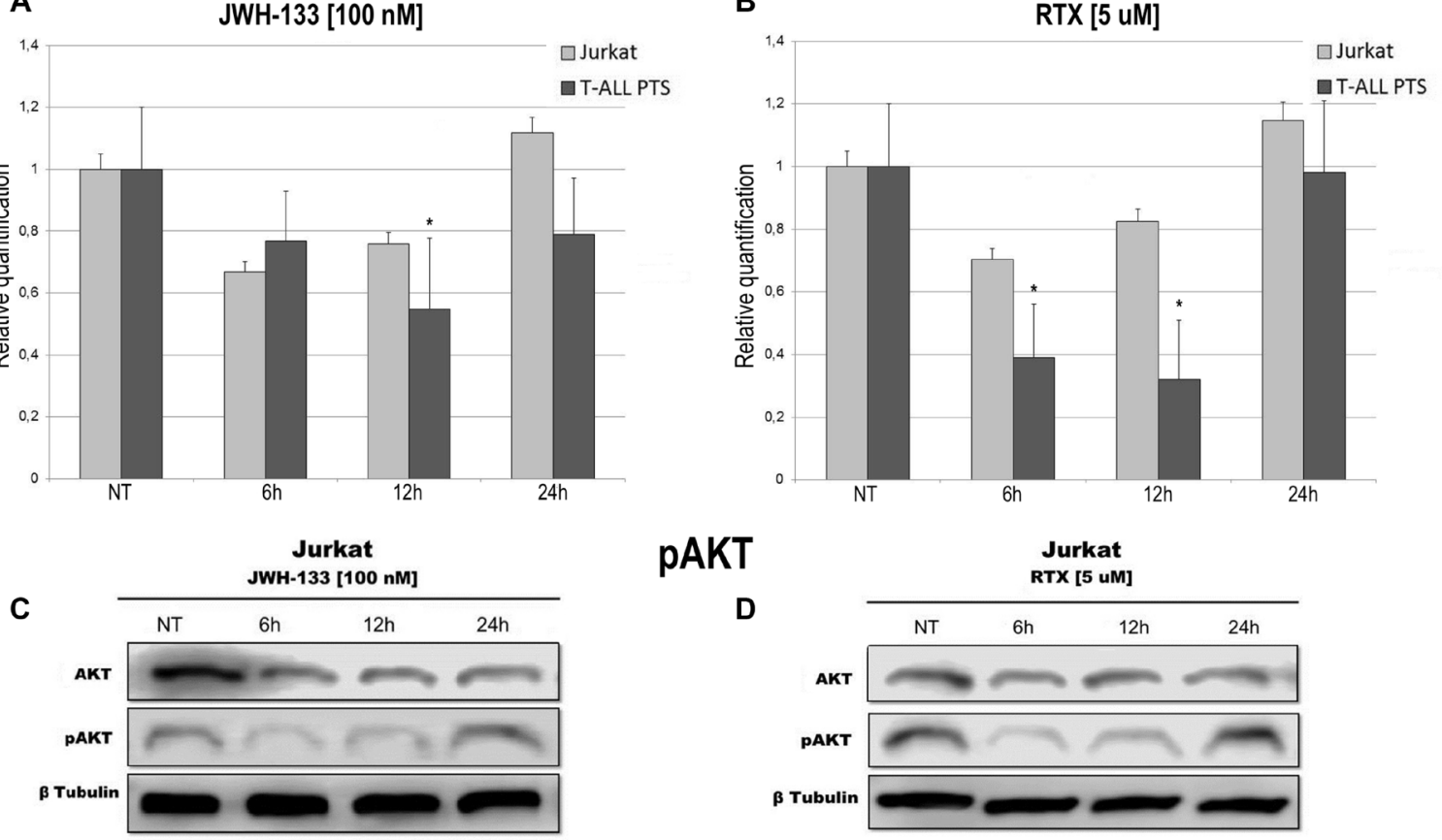

PAKT

D

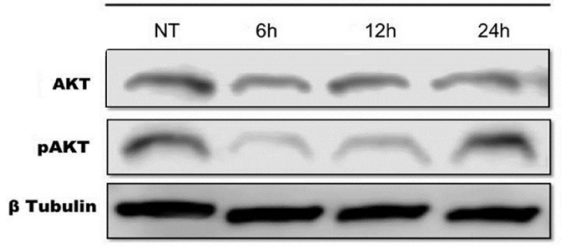

T-ALL PTS
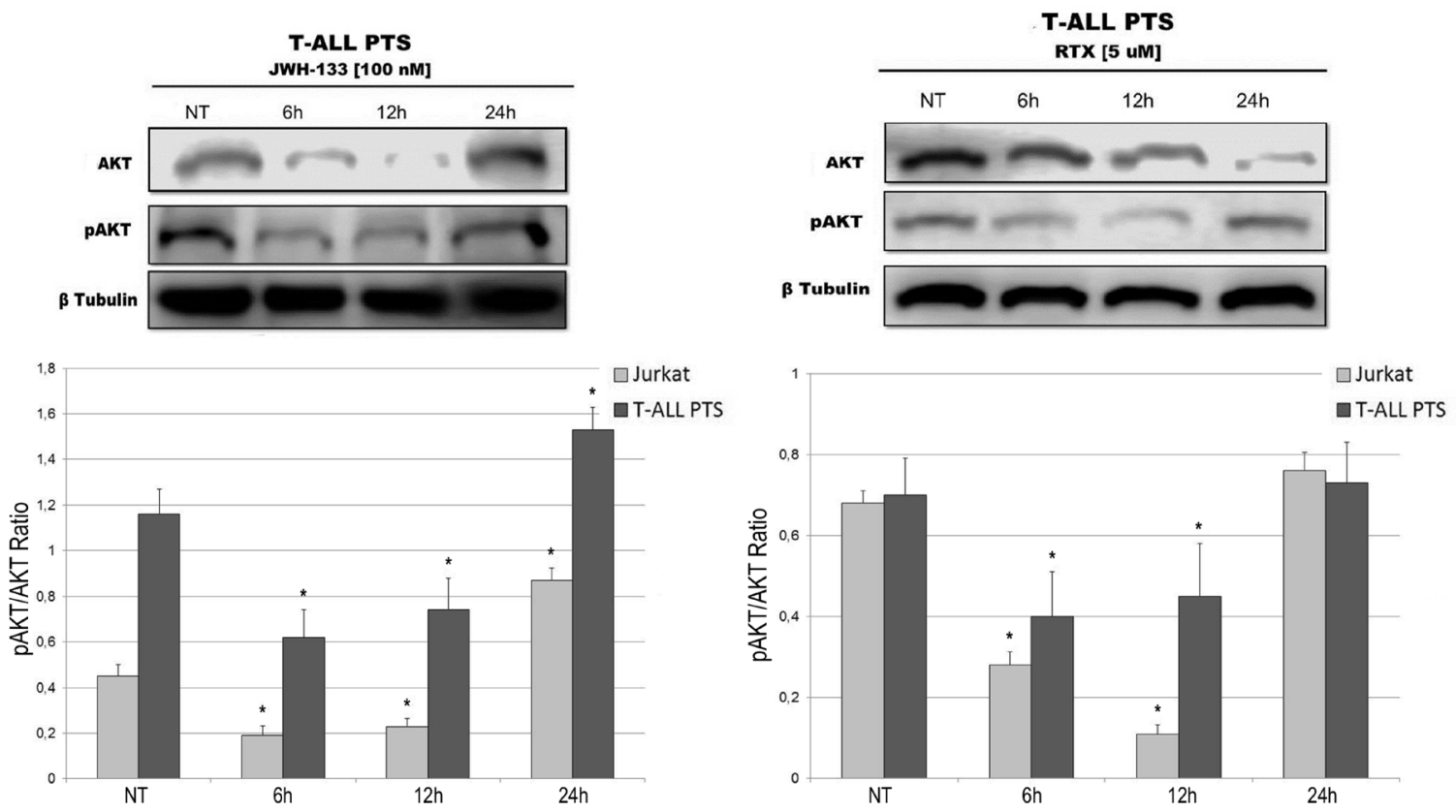

Figure 3: Effects of JWH-133 and RTX treatments on AKT mRNA expression levels and pAKT protein expression levels. AKT mRNA expression levels in Jurkat cell line and in T-ALL patients' lymphoblasts derived from 4 patients were determined by Q-PCR after JWH-133 [100 nM] (A) and RTX [5 uM] (B) treatments after $6 \mathrm{~h}, 12 \mathrm{~h}$ and $24 \mathrm{~h}$ of exposure. Results were normalized for the housekeeping gene $\beta$-actin and were showed as mean $\pm \mathrm{SD}$ of three independent experiments for Jurkat cells (performed in technical triplicate), and as mean $\pm \mathrm{SD}$ of four single experiments on each one of the 4 patients (performed in technical triplicate). A $t$-test has been used to evaluate statistical differences in AKT expression among groups. "indicates $p \leq 0.05$ compared to the untreated control (NT). AKT and pAKT protein expression levels in Jurkat cell line and in T-ALL patients' lymphoblasts, were determined by Western Blot, starting from $15 \mu \mathrm{g}$ of total lysates after JWH-133 [100 nM] (C) and RTX [5 uM] (D) treatments after $6 \mathrm{~h}, 12 \mathrm{~h}$ and $24 \mathrm{~h}$ of exposure. The images show the most representative blots. The proteins were detected using Image Studio Digit software and the intensity ratios of immunoblots compared to the one of the untreated control, taken as 1 (arbitrary unit), were quantified after normalizing with respective loading controls for the housekeeping protein $\beta$-tubulin. The graphs show the ratio between pAKT and AKT as the mean \pm SD of two independent experiments for Jurkat cells and as mean $\pm \mathrm{SD}$ of four single experiments on each one of the 4 patients. A $t$-test has been used to evaluate the statistical differences in protein expression levels. " indicates $p \leq 0.05$ compared to the untreated control (NT). 

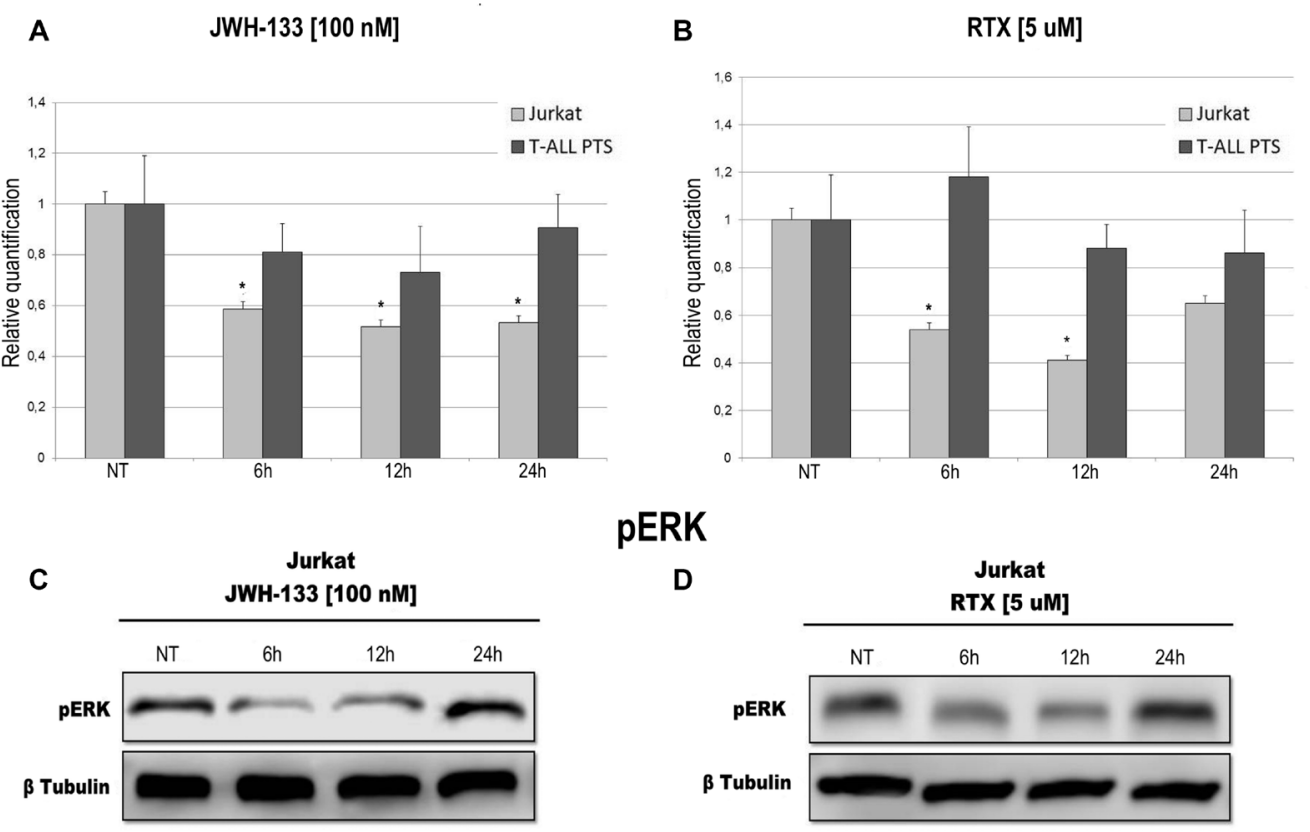

pERK
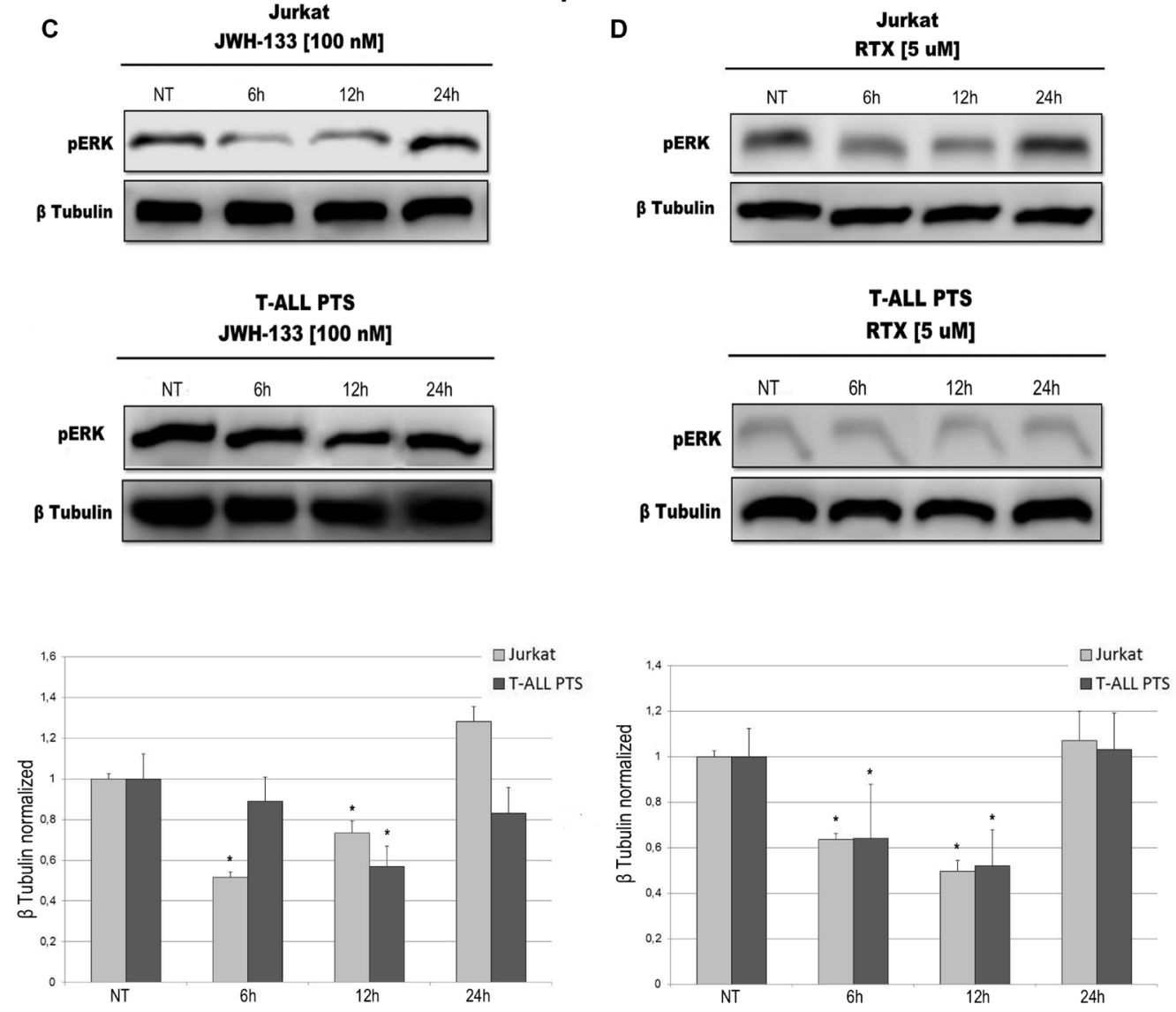

Figure 4: Effects of JWH-133 and RTX treatments on ERK mRNA expression levels and pERK protein expression levels. ERK mRNA expression levels in Jurkat cell line and in T-ALL patients' lymphoblasts derived from 4 patients were determined by Q-PCR after JWH-133 [100 nM] (A) and RTX [5 uM] (B) treatments at $6 \mathrm{~h}, 12 \mathrm{~h}$ and $24 \mathrm{~h}$ of exposure. Results were normalized for the housekeeping gene $\beta$-actin and were showed as mean $\pm \mathrm{SD}$ of three independent experiments for Jurkat cells (performed in technical triplicate), and as mean $\pm \mathrm{SD}$ of four single experiments on each one of the 4 patients (performed in technical triplicate). A $t$-test has been used to evaluate statistical differences in ERK expression among groups. "indicates $p \leq 0.05$ compared to the untreated control (NT). pERK protein expression levels in Jurkat cell line and in T-ALL patients' lymphoblasts, were determined by Western Blot, starting from $15 \mu \mathrm{g}$ of total lysates after JWH-133 [100 nM] (C) and RTX [5 uM] (D) treatments after $6 \mathrm{~h}, 12 \mathrm{~h}$ and $24 \mathrm{~h}$ of exposure. Images show the most representative blots. The proteins were detected using Image Studio Digits software and the intensity ratios of immunoblots compared to the untreated control, taken as 1 (arbitrary unit), were quantified after normalizing with respective loading controls for the housekeeping protein $\beta$-tubulin. The results were normalized for the housekeeping protein $\beta$-tubulin. The graphs represent the relative quantification for $\mathrm{pERK}$ expression as mean $\pm \mathrm{SD}$ from two independent experiments for Jurkat cells and as mean \pm SD of four single experiments on each one of the 4 patients. A $t$-test has been used to evaluate the statistical differences in protein expression levels. "indicates $p \leq 0.05$ compared to the untreated control (NT). 


\section{PTEN}

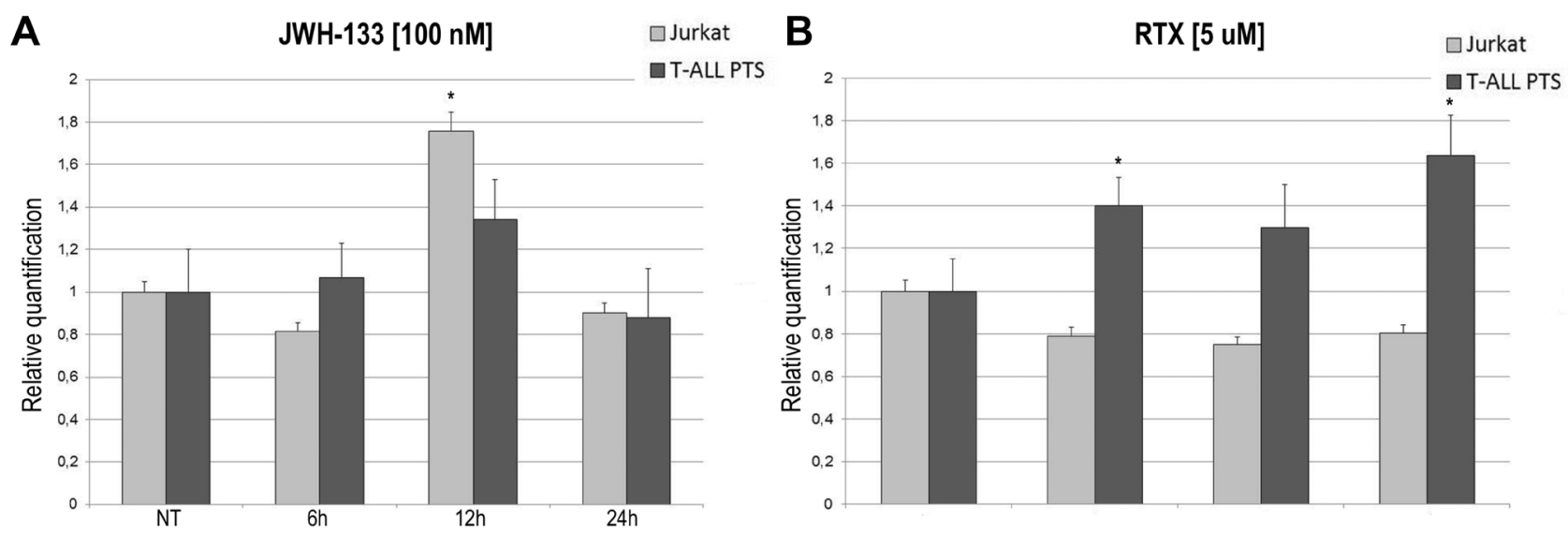

NOTCH-1

C

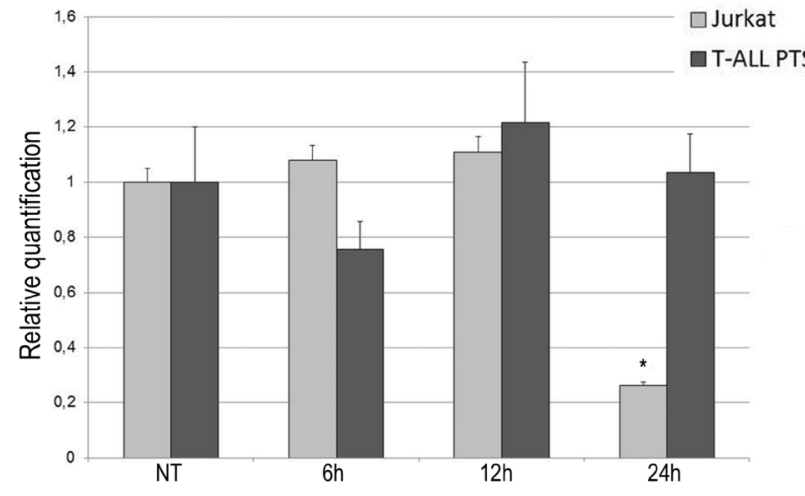

D

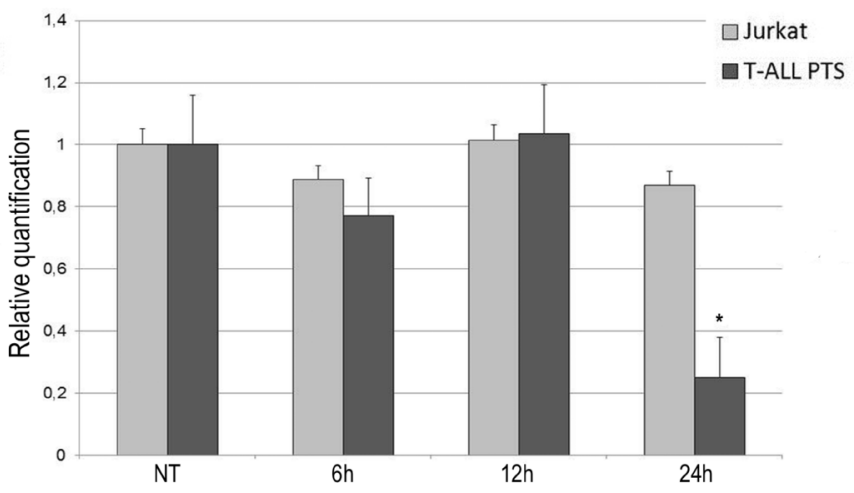

P53

E

JWH-133 [100 nM]

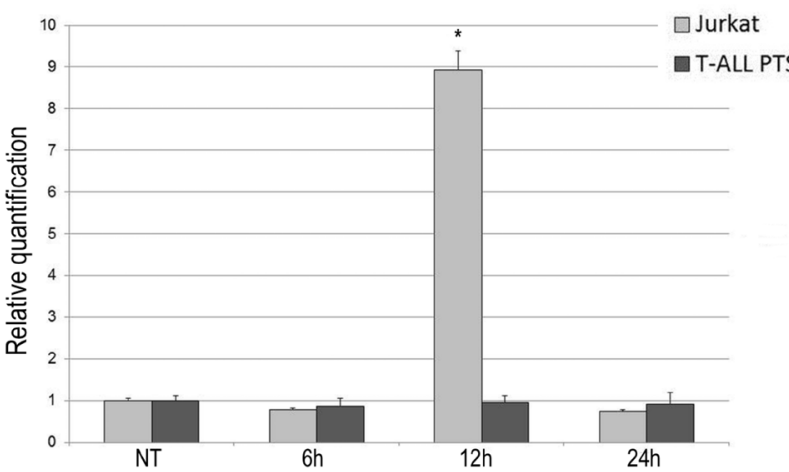

F

RTX [5 uM]

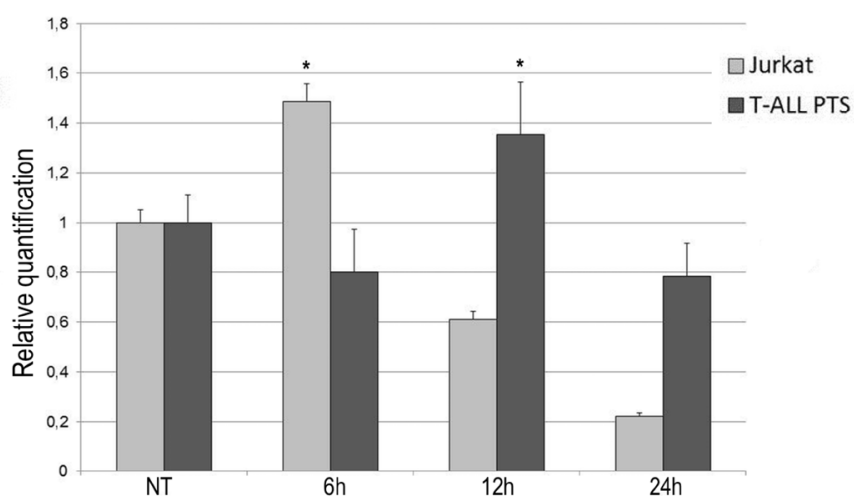

Figure 5: Effects of JWH-133 and RTX treatments on PTEN, NOTCH-1 and P53 mRNA expression levels. PTEN, NOTCH-1 and P53 mRNA expression levels in Jurkat cell line and in T-ALL patients' lymphoblasts derived from 4 patients were determined by Q-PCR after JWH-133 [100 nM] (A, C, E) and RTX [5uM] (B, D, F) treatments at $6 \mathrm{~h}, 12 \mathrm{~h}$ and $24 \mathrm{~h}$ of exposure. Results were normalized for the housekeeping gene $\beta$-actin and were showed as mean \pm SD of three independent experiments for Jurkat cells (performed in technical triplicate), and as mean \pm SD of four single experiments on each one of the 4 patients (performed in technical triplicate). A $t$-test has been used to evaluate statistical differences in PTEN, NOTCH-1 and P53 expression among groups. "indicates $p \leq$ 0.05 compared to the untreated control (NT). 
Table 2: Cell Cycle progression analysis of Jurkat cell line and T-ALL patients' lymphoblasts treated with JWH-133 and RTX

\begin{tabular}{|c|c|c|c|}
\hline \multicolumn{4}{|l|}{$\mathbf{A}$} \\
\hline Jurkat & G0/G1(\%) & $\mathrm{S}(\%)$ & G2/M(\%) \\
\hline NT & $38.5 \pm 3.5$ & $28.1 \pm 4.4$ & $33.1 \pm 3.8$ \\
\hline JWH-133 [100 nM] $6 \mathrm{~h}$ & $37.5 \pm 3.2$ & $45.3 \pm 3.6^{*}$ & $16.7 \pm 3.9^{*}$ \\
\hline JWH-133 [100 nM] $12 \mathrm{~h}$ & $37.0 \pm 4.4$ & $14.8 \pm 4.5^{*}$ & $48.2 \pm 3.8^{*}$ \\
\hline JWH-133 [100 nM] $24 \mathrm{~h}$ & $48.2 \pm 3.1^{*}$ & $12.6 \pm 2.8^{*}$ & $39.1 \pm 2.7$ \\
\hline JWH-133 [100 nM] $48 \mathrm{~h}$ & $46.8 \pm 3.3^{*}$ & $13.1 \pm 2.8^{*}$ & $39.9 \pm 2.4$ \\
\hline $\operatorname{RTX}[5 \mu \mathrm{M}] 6 \mathrm{~h}$ & $42.3 \pm 3.8$ & $36.8 \pm 3.4^{*}$ & $20.9 \pm 3.7^{*}$ \\
\hline $\operatorname{RTX}[5 \mu \mathrm{M}] 12 \mathrm{~h}$ & $39.1 \pm 4.5$ & $14.3 \pm 3.9^{*}$ & $46.6 \pm 3.9^{*}$ \\
\hline $\operatorname{RTX}[5 \mu \mathrm{M}] 24 \mathrm{~h}$ & $47.4 \pm 4.3^{*}$ & $12.6 \pm 3.2^{*}$ & $40.0 \pm 3.5$ \\
\hline $\operatorname{RTX}[5 \mu \mathrm{M}] 48 \mathrm{~h}$ & $49.6 \pm 4.6^{*}$ & $11.6 \pm 3.4^{*}$ & $38.5 \pm 3.6$ \\
\hline \multicolumn{4}{|l|}{ B } \\
\hline T-ALL T PTS & G0/G1(\%) & $S(\%)$ & G2/M(\%) \\
\hline NT & $26.64 \pm 4.5$ & $12.8 \pm 4.9$ & $60.56 \pm 4.7$ \\
\hline JHW-133 [100 nM] 6 h & $23.3 \pm 4.1$ & $12.0 \pm 4.6$ & $64.7 \pm 4.2$ \\
\hline JHW-133 [100 nM] $12 \mathrm{~h}$ & $26.1 \pm 4.9$ & $11.8 \pm 5.2$ & $62.1 \pm 5.1$ \\
\hline JHW-133 [100 nM] $24 \mathrm{~h}$ & $26.0 \pm 5.3$ & $10.7 \pm 4.8$ & $63.3 \pm 4.6$ \\
\hline JHW-133 [100 nM] $48 \mathrm{~h}$ & $26.9 \pm 5.1$ & $10.1 \pm 4.6$ & $63.0 \pm 4.5$ \\
\hline $\operatorname{RTX}[5 \mu \mathrm{M}] 6 \mathrm{~h}$ & $35.7 \pm 4.9$ & $11.7 \pm 5.1$ & $52.6 \pm 5.2$ \\
\hline $\operatorname{RTX}[5 \mu \mathrm{M}] 12 \mathrm{~h}$ & $27.4 \pm 4.6$ & $10.3 \pm 5.6$ & $62.3 \pm 5.7$ \\
\hline $\operatorname{RTX}[5 \mu \mathrm{M}] 24 \mathrm{~h}$ & $27.4 \pm 4.8$ & $9.3 \pm 5.6$ & $63.3 \pm 5.3$ \\
\hline $\operatorname{RTX}[5 \mu \mathrm{M}] 48 \mathrm{~h}$ & $27.1 \pm 4.9$ & $9.1 \pm 5.8$ & $63.8 \pm 5.1$ \\
\hline
\end{tabular}

Jurkat cell line and T-ALL patients' lymphoblasts were cultured and treated with JWH-133 [100 nM] and RTX [5 uM], for $6 \mathrm{~h}, 12 \mathrm{~h}, 24 \mathrm{~h}$ and $48 \mathrm{~h}$. Cells were harvested, fixed and then incubated with Muse Cell Cycle reagent for 30 minutes and analyzed on "MUSE Cell Analyzer". The percentage of cells accumulated at different phases of the cell cycle (G0/G1 phase, $\mathrm{S}$ phase and G2/M phase) are shown. The results are presented as the mean percentage $\pm \mathrm{SD}$ of three independent experiments for Jurkat cells (A) and 4 single experiment on each one of the 4 patients (B) and were analyzed by one-way analysis of variance (ANOVA). *indicates $p \leq 0.05$ compared to the untreated control (NT).

models, are required to provide a better insight on the importance of CB2 and TRPV1 in leukemia, to investigate the precise molecular mechanism of these antitumor activities and whether this co-administration could be effectively applied in clinical practice. In conclusion, our results strongly support the potential of EC/EV system as new therapeutic target in T-ALL, having demonstrated its capacity to interfere in proliferation and apoptosis of cancer cells by increasing/decreasing target genes involved in proliferation and apoptosis.

\section{MATERIALS AND METHODS}

\section{Patients}

Four Caucasic T-ALL patients referred to our center were included in this study. A girl of 5 years old, and three boys of 9,10 and 12 years old at the diagnosis.
These patients did not present cytogenetic alterations. A signed study subject informed consent was obtained from all subjects with the approval of Ethics Committee of the University of Campania "Luigi Vanvitelli" and in compliance with national legislation and the Code of Ethical Principles for Medical Research Involving Human Subjects of the World Medical Association (Declaration of Helsinki)

\section{Cell cultures}

Jurkat cell line has been purchased from SigmaAldrich. The patient's Lymphoblasts were obtained from peripheral blood mononuclear cells (PBMCs) isolated by centrifugation over Histopaque 1077 density gradient (Sigma). Jurkat cell lines and patient's Lymphoblasts were cultured in RPMI medium with $10 \%$ fetal bovine serum (FBS), supplemented with $100 \mathrm{U} / \mathrm{ml}$ penicillin (Gibco), $100 \mathrm{U} / \mathrm{ml}$ streptomycin (Gibco) and 
CDK2

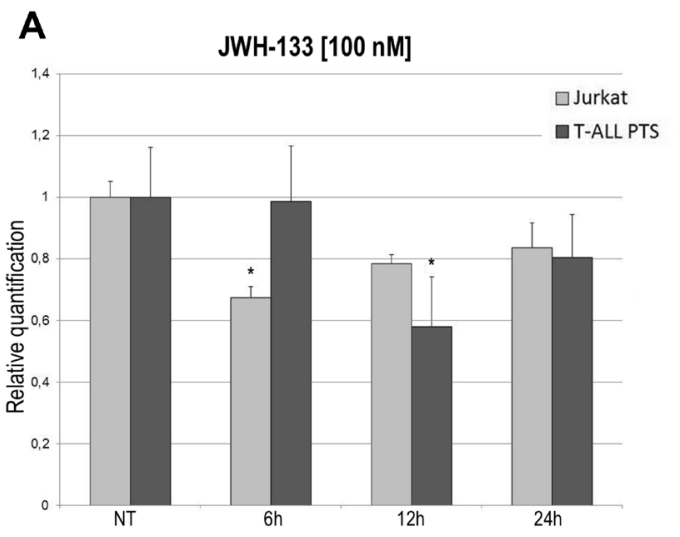

\section{B}

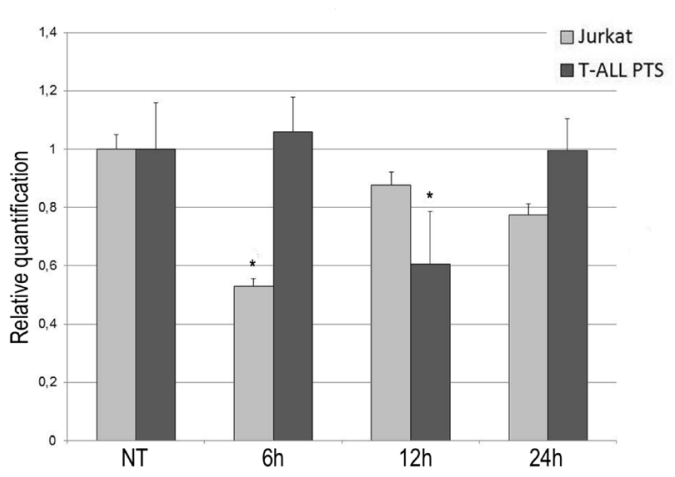

PCDK2
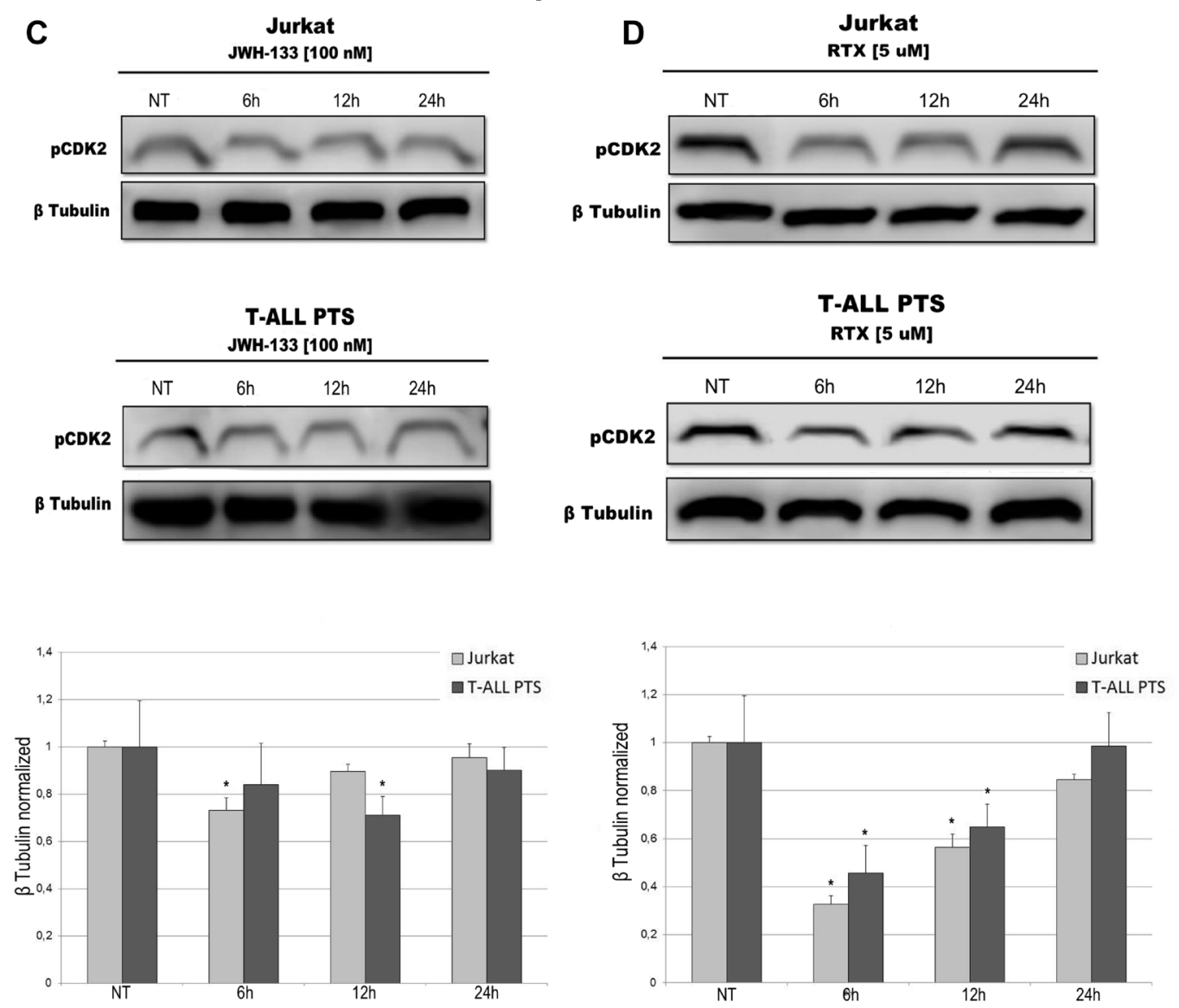

Figure 6: Effects of JWH-133 and RTX treatments on CDK2 mRNA expression levels and pCDK2 protein expression levels. CDK2 mRNA expression levels in Jurkat cell line and in T-ALL patients' lymphoblasts derived from 4 patients were determined by Q-PCR after JWH-133 [100 nM] (A) and RTX [5 uM] (B) treatments at $6 \mathrm{~h}, 12 \mathrm{~h}$ and $24 \mathrm{~h}$ of exposure. Results were normalized for the housekeeping gene $\beta$-actin and were showed as mean $\pm \mathrm{SD}$ of three independent experiments for Jurkat cells (performed in technical triplicate), and as mean $\pm \mathrm{SD}$ of four single experiments on each one of the 4 patients (performed in technical triplicate). A $t$-test has been used to evaluate statistical differences in CDK2 expression among groups. "indicates $p \leq 0.05$ compared to the untreated control (NT). pCDK2 protein expression levels in Jurkat cell line and in T-ALL patients' lymphoblasts, were determined by Western Blot, starting from $15 \mu \mathrm{g}$ of total lysates after JWH-133 [100 nM] (C) and RTX [5 uM] (D) treatments after $6 \mathrm{~h}, 12 \mathrm{~h}$ and $24 \mathrm{~h}$ of exposure. Images show the most representative blots. The proteins were detected using Image Studio Digit software and the intensity ratios of immunoblots compared to that of untreated control, taken as 1 (arbitrary unit), were quantified after normalizing with respective loading controls for the housekeeping protein $\beta$-tubulin. The graphs represent the relative quantification for $\mathrm{pCDK} 2$ expression as mean $\pm \mathrm{SD}$ of two independent experiments for Jurkat cells and as mean $\pm \mathrm{SD}$ of four single experiments on each one of the 4 patients. A $t$-test has been used to evaluate the statistical differences in protein expression levels. ${ }^{*}$ indicates $p \leq 0.05$ compared to the untreated control (NT). 
$2 \mathrm{mM}$ L-glutamine (Euroclone). Cells were cultured at $37^{\circ} \mathrm{C}$ in a humidified atmosphere with $5 \% \mathrm{CO}_{2}$.

\section{Drugs and treatments}

Resiniferatoxin (RTX- Potent analog of capsaicin, that is an agonist at vanilloid receptors) and JWH133 (Potent CB2 selective agonist. Approx. 200-fold selective over $\mathrm{CB} 1$ receptors) were purchased from Tocris Bioscience (Bristol, UK). The powder was dissolved in dimethyl sulfoxide (DMSO) at a concentration of $50 \mathrm{mM}$ for JWH-133. RTX was dissolved in DMSO to a stock solution of $100 \mathrm{mM}$. DMSO final concentration on cell cultures was $0.01 \%$. Stock solutions were aliquoted and kept at $-80^{\circ} \mathrm{C}$ for long-term storage. Jurkat and primary cell lines were treated with EC/EV compounds alone at concentrations of RTX [5 uM] and JWH-133 [100 $\mathrm{nM}]$. Non-treated cultured cell lines were maintained in incubation media during the relative treatment time with and without vehicle (DMSO 0.01\%).

\section{Annexin, count and viability}

Apoptosis has been evaluated by a fluorometric assay on the Muse cell analyser machine with the "Cell dead and Annexin V Assay Kit". Test was performed after $6 \mathrm{~h}, 12 \mathrm{~h}$ and $24 \mathrm{~h}$ of EC/EV compounds exposure. EC/ $\mathrm{EV}$ active compounds were added alone at the following concentrations: JWH-133 [100 nM], RTX [5 uM]. The Muse $^{\mathrm{TM}}$ Annexin V \& Dead Cell Assay utilizes Annexin $\mathrm{V}$ to detect phosphatidylserine (PS) on the external membrane of apoptotic cells. A dead cell marker, is also used as an indicator of cell membrane structural integrity,7amino-actinomycin D (7-AAD). Briefly, $100 \mu \mathrm{L}$ of a cell suspension $\left(1 \times 10^{4}\right.$ cells $\left./ \mathrm{mL}\right)$ was mixed with $100 \mu \mathrm{L}$ of Muse $^{\mathrm{TM}}$ Annexin V \& Dead Cell Reagent and incubated for 20 minutes at room temperature in dark. The results, automatically displayed, were analyzed with "Muse 1.4 Analysis" software for data acquisition and analysis.

\section{Cell cycle assay}

Cell cycle has been evaluated by a fluorometric assay on the Muse cell analyser machine with the "Cell Cycle Assay Kit". Test was performed after $6 \mathrm{~h}$, $12 \mathrm{~h}$ and $24 \mathrm{~h}$ of EC/EV compounds exposure. EC/EV active compounds were added alone at the following concentrations: JWH-133 [100 nM], RTX [5 uM]. The Muse $^{\mathrm{TM}}$ Cell Cycle Assay utilizes a propidium iodide (PI)-based staining of DNA content to discriminate and measure the percentage of cells in each cell cycle phase (G0/G1, S, and G2/M). Briefly, Jurkat and Lymphoblasts cells were fixed in $70 \%$ ice-cold ethanol for at least 30 minutes, washed and incubated with Cell Cycle reagent for 2 hours at room temperature in dark. The results, automatically displayed, were analyzed with "Muse 1.4 Analysis" software for data acquisition and analysis.

\section{Total RNA extraction and reverse transcription quantitative polymerase chain reaction (RTqPCR)}

Following treatment with JWH-133 $[100 \mathrm{nM}]$ and RTX [5 uM] and incubation for $6 \mathrm{~h}, 12 \mathrm{~h}$ and $24 \mathrm{~h}$ at $37^{\circ} \mathrm{C}$ with $5 \% \mathrm{CO}_{2}$, OS cells were harvested. Cells without treatment served as the control group. The total RNA was extracted using Quiazol ${ }^{\circledR}$ (Quiagen) following the manufacturer's instructions. EasyScript ${ }^{\mathrm{TM}} \mathrm{cDNA}$ Synthesis Kit $(a b m)$ was used to synthesize from approximately 1000 ng mRNA, the first strand cDNA. The transcript levels of AKT serine/threonine kinase (AKT), mitogenactivated protein kinase 1 (MAPK1/ERK), phosphatase and tensin homolog (PTEN), Notch-1, cyclin dependent kinase 2 (CDK2), tumor protein p53 (p53) and Caspase-3 (CASP3) were detected by RT-qPCR using a CFX96 Real-Time PCR system (Bio-Rad) using I-Taq Universal SYBR $^{\circledR}$ Green Master Mix (Bio-Rad). The cycling conditions were $10 \mathrm{~min}$ at $95^{\circ} \mathrm{C}$ (initial denaturation) followed by 40 cycles of $15 \mathrm{sec}$ at $94^{\circ} \mathrm{C}$ (denaturation) and $1 \mathrm{~min}$ at $68^{\circ} \mathrm{C}$ (annealing/extension/data collection). The $\beta$-Actin gene served as the reference gene for the normalization of the real-time PCR products. The PCR primers used to detect each gene were designed using Primer 3 program and synthesized by Sigma Aldrich (CB2_F 5'-AAGGCTGTCTTCCTGCTGAA-3', CB2_R 5'- CACAGAGGCTGTGAAGGTCA-3, TRPV1_F 5'-CTG CAGAAGAGCAAGAAGCA-3', TRPV1_R 5'-ATGGC TTTCAGCAGACAGGT-3', AKT_F 5'-GCTCACCCAG TGACAACTCA-3', AKT_R 5'- CCCAGCAGCTTCAG GTACTC-3', ERK_F 5'- GTGACCTCAAGCCTTCCA AC-3', ERK R 5'- TTCTGGAGCCCTGTACCAAC-3', PTEN_F 5'-TCCACAAACAGAACAAGATGCT-3', PTEN_R 5'-GGTTTCCTCTGGTCCTGGTA -3', Notch1_F 5'-TCCTTCTACTGCGAGTGTCC-3', Notch1_R 5'- TCG TTACAGGGGTTGCTGAT - 3', CDK2 F 5'- TCACTGGC ATTCCTCTTCCC -3', CDK2 R 5'- ACCCGATGAGAA TGGCAGAA -3', p53_F 5'- CCTCACCATCATCACA CTGG -3', p53_R 5'- TTGCGGAGATTCTCTTCCTC -3', Caspase3_F 5'-TTGTGGAATTGATGCGTGAT-3', Caspase 3_R 5'-TGGCTCAGAAGCACACAAAC-3', $\beta$-Actin_F 5'-GCGAGAAGATGACCCAGATC-3', $\beta$-Actin_R 5'-GGA TAGCACAGCCTGGATAG-3'). The linearity and efficiency of the assays were tested over dilutions of input cDNA spanning five orders of magnitude. Assays were performed in technical triplicate, for three times on Jurkat cells (displayed as mean $\pm \mathrm{SD}$ ) and one time for each one of the 4 patients (displayed as mean $\pm \mathrm{SD}$ ). The dissociation curve analysis of amplification products was performed at the end of each PCR reaction to confirm the specificity of the amplification. The $2^{-\Delta \Delta \mathrm{Ct}}$ method was used to analyze 
the data and obtain the relative gene expression levels compared to the controls.

\section{Western blotting}

Proteins were extracted from treated and nontreated primary T-Cell ALL patient's and Jurkat cell line using RIPA Lysis Buffer (Millipore) and following the manufacturer's instructions. pAKT, pERK Bcl-2, Bax, ProCaspase 3, and $\mathrm{pCDK} 2$ proteins were characterized in total lysates from cell cultures by Western blotting. Membranes were incubated overnight at $4^{\circ} \mathrm{C}$ with rabbit polyclonal anti pAKT antibody (1:200 dilution; Santa Cruz), mouse polyclonal anti pERK (1:200 dilution; Santa Cruz), mouse polyclonal anti Bcl-2 (1:500 dilution; Santa Cruz), rabbit polyclonal anti Bax antibody (1:1000 dilution; Cell Signaling), mouse polyclonal anti-Pro-Caspase 3 antibody (1:1000 dilution; Abcam), rabbit polyclonal anti pCDK2 (1:1200 dilution; Abcam). For determination of Bax and Bcl-2 ratio, antibodies against both proteins were used subsequently on the same membrane. Reactive bands were detected by chemiluminescence (Immobilon western Millipore) on a C-DiGit ${ }^{\circledR}$ Blot Scanner (LICOR Biosciences). A mouse polyclonal anti $\beta$-Tubulin antibody (1:1000 dilution; Sigma) was used to check for comparable protein loading and as a housekeeping protein. We performed two experiments on Jurkat cells (displayed as mean $\pm \mathrm{SD}$ ) and single experiments on each one of the 4 T-ALL patients' samples (displayed as mean $\pm \mathrm{SD}$ ). Images were captured, stored, and analyzed using "Image studio Digits ver. 5.0" software.

\section{Statistical analysis}

Results are expressed as means \pm S.D. The experiments were run in technical triplicate for Real Time PCR. When performing Western Blotting, two times for Jurkat cells and displayed as mean $\pm \mathrm{SD}$, single experiments on each one of the 4 T-ALL patient's and displayed as mean of all of them $\pm \mathrm{SD}$. Statistical analyses on molecular and biochemical data were performed using Student's $t$ test to evaluate differences between quantitative variables. Statistical analyses on apoptosis and cell cycle data were performed using one-way analysis of variance, ANOVA (StatGraphics Centurion XV.II Software. Adalta, Arezzo, Italy; Statpoint Technologies Inc., VA). A p value less than 0.05 was considered statistically significant.

\section{ACKNOWLEDGMENTS}

The authors thank Maura Argenziano for the help in performing the experiments.

\section{CONFLICTS OF INTEREST}

The authors declare no conflicts of interest.

\section{FUNDING}

This work was partly supported by grant from "Progetti di Rilevante Interesse Nazionale" (PRIN) and from "POR Campania FESR 2007/2013 Title: "MOdelli in VIvo di patologie umanE- MOVIE".

\section{REFERENCES}

1. Terwilliger T, Abdul-Hay M. Acute lymphoblastic leukemia: a comprehensive review and 2017 update. Blood Cancer J. 2017; 7:e577. https://doi.org/10.1038/bcj.2017.53.

2. Jin MW, Xu SM, An Q, Wang P. A review of risk factors for childhood leukemia. Eur Rev Med Pharmacol Sci. 2016; $20: 3760-4$.

3. Bhojwani D, Yang JJ, Pui CH. Biology of childhood acute lymphoblastic leukemia. Pediatr Clin North Am. 2015; 62:47-60. https://doi.org/10.1016/j.pcl.2014.09.004.

4. Vrooman LM, Silverman LB. Treatment of Childhood Acute Lymphoblastic Leukemia: Prognostic Factors and Clinical Advances. Curr Hematol Malig Rep. 2016; 11:38594. https://doi.org/10.1007/s11899-016-0337-y.

5. Fardell JE, Vetsch J, Trahair T, Mateos MK, Grootenhuis MA, Touyz LM, Marshall GM, Wakefield CE. Healthrelated quality of life of children on treatment for acute lymphoblastic leukemia: A systematic review. Pediatr Blood Cancer. 2017; 64:e26489. https://doi.org/10.1002/pbc.26489.

6. Layton Tovar CF, Mendieta Zeron H. Intracellular Signaling Pathways Involved in Childhood Acute Lymphoblastic Leukemia; Molecular Targets. Indian J Hematol Blood Transfus. 2016; 32:141-53. https://doi.org/10.1007/ s12288-015-0609-z.

7. Karrman K, Johansson B. Pediatric T-cell acute lymphoblastic leukemia. Genes Chromosomes Cancer. 2016. https://doi.org/10.1002/gcc.22416.

8. Matloub Y, Stork L, Asselin B, Hunger SP, Borowitz M, Jones T, Bostrom B, Gastier-Foster JM, Heerema NA, Carroll A, Winick N, Carroll WL, Camitta B, et al. Outcome of Children with Standard-Risk T-Lineage Acute Lymphoblastic Leukemia - Comparison among Different Treatment Strategies. Pediatr Blood Cancer. 2016; 63:25561. https://doi.org/10.1002/pbc.25793.

9. Jaing TH, Yang CP, Hung IJ, Tsay PK, Tseng CK, Chen SH. Clinical significance of central nervous system involvement at diagnosis of childhood T-cell acute lymphoblastic leukemia. Pediatr Blood Cancer. 2005; 45:135-8. https:// doi.org/10.1002/pbc.20316.

10. Flygare J, Gustafsson K, Kimby E, Christensson B, Sander B. Cannabinoid receptor ligands mediate growth inhibition and cell death in mantle cell lymphoma. FEBS Lett. 2005; 579:6885-9. https://doi.org/10.1016/j.febslet.2005.11.020.

11. Gustafsson K, Christensson B, Sander B, Flygare J. Cannabinoid receptor-mediated apoptosis induced by $\mathrm{R}(+)$-methanandamide and Win55,212-2 is associated with 
ceramide accumulation and p38 activation in mantle cell lymphoma. Mol Pharmacol. 2006; 70:1612-20. https://doi. org/10.1124/mol.106.025981.

12. Jia W, Hegde VL, Singh NP, Sisco D, Grant S, Nagarkatti M, Nagarkatti PS. Delta9-tetrahydrocannabinol-induced apoptosis in Jurkat leukemia $\mathrm{T}$ cells is regulated by translocation of Bad to mitochondria. Mol Cancer Res. 2006; 4:549-62. https://doi.org/10.1158/1541-7786. MCR-05-0193.

13. Jorda MA, Rayman N, Valk P, De Wee E, Delwel R. Identification, characterization, and function of a novel oncogene: the peripheral cannabinoid receptor $\mathrm{Cb} 2$. Ann $\mathrm{N}$ Y Acad Sci. 2003; 996:10-6.

14. Kampa-Schittenhelm KM, Salitzky O, Akmut F, Illing B, Kanz L, Salih HR, Schittenhelm MM. Dronabinol has preferential antileukemic activity in acute lymphoblastic and myeloid leukemia with lymphoid differentiation patterns. BMC Cancer. 2016; 16:25. https://doi.org/10.1186/ s12885-015-2029-8.

15. Rieder SA, Chauhan A, Singh U, Nagarkatti M, Nagarkatti P. Cannabinoid-induced apoptosis in immune cells as a pathway to immunosuppression. Immunobiology. 2010; 215:598-605. https://doi.org/10.1016/j.imbio.2009.04.001.

16. Nabissi M, Morelli MB, Offidani M, Amantini C, Gentili S, Soriani A, Cardinali C, Leoni P, Santoni G. Cannabinoids synergize with carfilzomib, reducing multiple myeloma cells viability and migration. Oncotarget. 2016; 7:7754357. https://doi.org/10.18632/oncotarget.12721.

17. Parsons LH, Hurd YL. Endocannabinoid signalling in reward and addiction. Nat Rev Neurosci. 2015; 16:579-94. https://doi.org/10.1038/nrn4004.

18. Tantimonaco M, Ceci R, Sabatini S, Catani MV, Rossi A, Gasperi V, Maccarrone M. Physical activity and the endocannabinoid system: an overview. Cell Mol Life Sci. 2014; 71:2681-98. https://doi.org/10.1007/ s00018-014-1575-6.

19. Smart D, Gunthorpe MJ, Jerman JC, Nasir S, Gray J, Muir AI, Chambers JK, Randall AD, Davis JB. The endogenous lipid anandamide is a full agonist at the human vanilloid receptor (hVR1). Br J Pharmacol. 2000; 129:227-30. https://doi.org/10.1038/sj.bjp.0703050.

20. Di Marzo V, De Petrocellis L. Why do cannabinoid receptors have more than one endogenous ligand? Philos Trans R Soc Lond B Biol Sci. 2012; 367:3216-28. https:// doi.org/10.1098/rstb.2011.0382.

21. De Petrocellis L, Di Marzo V. Role of endocannabinoids and endovanilloids in Ca2+ signalling. Cell Calcium. 2009; 45:611-24. https://doi.org/10.1016/j.ceca.2009.03.003.

22. Lin $\mathrm{CH}, \mathrm{Lu} \mathrm{WC}$, Wang CW, Chan YC, Chen MK. Capsaicin induces cell cycle arrest and apoptosis in human $\mathrm{KB}$ cancer cells. BMC Complement Altern Med. 2013; 13:46. https:// doi.org/10.1186/1472-6882-13-46.

23. Maccarrone M, Lorenzon T, Bari M, Melino G, FinazziAgro A. Anandamide induces apoptosis in human cells via vanilloid receptors. Evidence for a protective role of cannabinoid receptors. J Biol Chem. 2000; 275:31938-45. https://doi.org/10.1074/jbc.M005722200.

24. Rossi F, Siniscalco D, Luongo L, De Petrocellis L, Bellini G, Petrosino S, Torella M, Santoro C, Nobili B, Perrotta S, Di Marzo V, Maione S. The endovanilloid/endocannabinoid system in human osteoclasts: possible involvement in bone formation and resorption. Bone. 2009; 44:476-84. https:// doi.org/10.1016/j.bone.2008.10.056.

25. Rossi F, Bellini G, Luongo L, Torella M, Mancusi S, De Petrocellis L, Petrosino S, Siniscalco D, Orlando P, Scafuro M, Colacurci N, Perrotta S, Nobili B, et al, and Endocannabinoid Research Group (ERG), Italy. The endovanilloid/endocannabinoid system: a new potential target for osteoporosis therapy. Bone. 2011; 48:997-1007. https://doi.org/10.1016/j.bone.2011.01.001.

26. Rossi F, Bellini G, Tortora C, Bernardo ME, Luongo L, Conforti A, Starc N, Manzo I, Nobili B, Locatelli F, Maione $\mathrm{S}$. $\mathrm{CB}(2)$ and $\mathrm{TRPV}(1)$ receptors oppositely modulate in vitro human osteoblast activity. Pharmacol Res. 2015; 99:194-201. https://doi.org/10.1016/j.phrs.2015.06.010.

27. Bellini G, Torella M, Manzo I, Tortora C, Luongo L, Punzo F, Colacurci N, Nobili B, Maione S, Rossi F. PKCbetaIImediated cross-talk of TRPV1/CB2 modulates the glucocorticoid-induced osteoclast overactivity. Pharmacol Res. 2016. https://doi.org/10.1016/j.phrs.2016.11.039.

28. Chakravarti B, Ravi J, Ganju RK. Cannabinoids as therapeutic agents in cancer: current status and future implications. Oncotarget. 2014; 5:5852-72. https://doi. org/10.18632/oncotarget.2233.

29. De Petrocellis L, Bisogno T, Ligresti A, Bifulco M, Melck D, Di Marzo V. Effect on cancer cell proliferation of palmitoylethanolamide, a fatty acid amide interacting with both the cannabinoid and vanilloid signalling systems. Fundam Clin Pharmacol. 2002; 16:297-302.

30. Velasco G, Sanchez C, Guzman M. Anticancer mechanisms of cannabinoids. Curr Oncol. 2016; 23:S23-32. https://doi. org/10.3747/co.23.3080.

31. Vidinsky B, Gal P, Pilatova M, Vidova Z, Solar P, Varinska L, Ivanova L, Mojzis J. Anti-proliferative and anti-angiogenic effects of CB2R agonist (JWH-133) in non-small lung cancer cells (A549) and human umbilical vein endothelial cells: an in vitro investigation. Folia Biol (Praha). 2012; 58:75-80.

32. Punzo F, Tortora C, Di Pinto D, Manzo I, Bellini G, Casale F, Rossi F. Anti-proliferative, pro-apoptotic and antiinvasive effect of EC/EV system in human osteosarcoma. Oncotarget. 2017; 8:54459-71. https://doi.org/10.18632/ oncotarget.17089.

33. McKallip RJ, Lombard C, Fisher M, Martin BR, Ryu S, Grant S, Nagarkatti PS, Nagarkatti M. Targeting CB2 cannabinoid receptors as a novel therapy to treat malignant lymphoblastic disease. Blood. 2002; 100:627-34. https:// doi.org/10.1182/blood-2002-01-0098.

34. McKallip RJ, Jia W, Schlomer J, Warren JW, Nagarkatti PS, Nagarkatti M. Cannabidiol-induced apoptosis in human 
leukemia cells: A novel role of cannabidiol in the regulation of p22phox and Nox4 expression. Mol Pharmacol. 2006; 70:897-908. https://doi.org/10.1124/mol.106.023937.

35. Samivel R, Kim DW, Son HR, Rhee YH, Kim EH, Kim JH, Bae JS, Chung YJ, Chung PS, Raz E, Mo JH. The role of TRPV1 in the CD4+ T cell-mediated inflammatory response of allergic rhinitis. Oncotarget. 2016; 7:148-60. https://doi.org/10.18632/oncotarget.6653.

36. Burz C, Berindan-Neagoe I, Balacescu O, Irimie A. Apoptosis in cancer: key molecular signaling pathways and therapy targets. Acta Oncol. 2009; 48:811-21. https://doi. org/10.1080/02841860902974175.

37. Devarajan E, Sahin AA, Chen JS, Krishnamurthy RR, Aggarwal N, Brun AM, Sapino A, Zhang F, Sharma D, Yang XH, Tora AD, Mehta K. Down-regulation of caspase 3 in breast cancer: a possible mechanism for chemoresistance. Oncogene. 2002; 21:8843-51. https://doi.org/10.1038/ sj.onc. 1206044 .

38. Mata JF, Silveira VS, Mateo EC, Cortez MA, Queiroz RG, Yunes JA, Lee ML, Toledo SR, Petrilli AS, Brandalise SR, Tone LG, Scrideli CA. Low mRNA expression of the apoptosis-related genes CASP3, CASP8, and FAS is associated with low induction treatment response in childhood acute lymphoblastic leukemia (ALL). Pediatr Blood Cancer. 2010; 55:100-7. https://doi.org/10.1002/ pbc. 22463.

39. McCubrey JA, Steelman LS, Chappell WH, Abrams SL, Wong EW, Chang F, Lehmann B, Terrian DM, Milella M, Tafuri A, Stivala F, Libra M, Basecke J, et al. Roles of the Raf/ MEK/ERK pathway in cell growth, malignant transformation and drug resistance. Biochim Biophys Acta. 2007; 1773:126384. https://doi.org/10.1016/j.bbamcr.2006.10.001.

40. Jiang BH. PI3K/AKT and mTOR/p70S6K1 signaling pathways in human cancer. Curr Cancer Drug Targets. 2013; 13:233.

41. Steelman LS, Franklin RA, Abrams SL, Chappell W, Kempf CR, Basecke J, Stivala F, Donia M, Fagone P, Nicoletti F, Libra M, Ruvolo P, Ruvolo V, et al. Roles of the Ras/Raf/MEK/ERK pathway in leukemia therapy. Leukemia. 2011; 25:1080-94. https://doi.org/10.1038/leu.2011.66.

42. Zuurbier L, Petricoin EF 3rd, Vuerhard MJ, Calvert V, Kooi C, Buijs-Gladdines JG, Smits WK, Sonneveld E, Veerman AJ, Kamps WA, Horstmann M, Pieters R, Meijerink JP. The significance of PTEN and AKT aberrations in pediatric T-cell acute lymphoblastic leukemia. Haematologica. 2012; 97:1405-13. https://doi.org/10.3324/haematol.2011.059030.

43. Tesio M, Trinquand A, Macintyre E, Asnafi V. Oncogenic PTEN functions and models in T-cell malignancies. Oncogene. 2016; 35:3887-96. https://doi.org/10.1038/onc.2015.462.
44. Mendes RD, Cante-Barrett K, Pieters R, Meijerink JP. The relevance of PTEN-AKT in relation to NOTCH1-directed treatment strategies in T-cell acute lymphoblastic leukemia. Haematologica. 2016; 101:1010-7. https://doi.org/10.3324/ haematol.2016.146381.

45. Jotta PY, Ganazza MA, Silva A, Viana MB, da Silva MJ, Zambaldi LJ, Barata JT, Brandalise SR, Yunes JA. Negative prognostic impact of PTEN mutation in pediatric T-cell acute lymphoblastic leukemia. Leukemia. 2010; 24:239-42. https://doi.org/10.1038/leu.2009.209.

46. Zou J, Li P, Lu F, Liu N, Dai J, Ye J, Qu X, Sun X, Ma D, Park J, Ji C. Notch1 is required for hypoxia-induced proliferation, invasion and chemoresistance of T-cell acute lymphoblastic leukemia cells. J Hematol Oncol. 2013; 6:3. https://doi.org/Artn310.1186/1756-8722-6-3.

47. Guo D, Ye J, Dai J, Li L, Chen F, Ma D, Ji C. Notch-1 regulates Akt signaling pathway and the expression of cell cycle regulatory proteins cyclin D1, CDK2 and p21 in T-ALL cell lines. Leuk Res. 2009; 33:678-85. https://doi. org/10.1016/j.leukres.2008.10.026.

48. Schmitz NM, Leibundgut K, Hirt A. CDK2 catalytic activity and loss of nuclear tethering of retinoblastoma protein in childhood acute lymphoblastic leukemia. Leukemia. 2005; 19:1783-7. https://doi.org/10.1038/sj.leu.2403900.

49. Casimiro MC, Crosariol M, Loro E, Li Z, Pestell RG. Cyclins and cell cycle control in cancer and disease. Genes Cancer. 2012; 3:649-57. https://doi.org/10.1177/1947601913479022.

50. Salmoiraghi S, Rambaldi A, Spinelli O. TP53 in adult acute lymphoblastic leukemia. Leuk Lymphoma. 2017; 1-12. https://doi.org/10.1080/10428194.2017.1344839.

51. Holmberg Olausson K, Nister M, Lindstrom MS. p53 -Dependent and -Independent Nucleolar Stress Responses. Cells. 2012; 1:774-98. https://doi.org/10.3390/cells1040774.

52. Hof J, Krentz S, van Schewick C, Körner G, Shalapour S, Rhein P, Karawajew L, Ludwig WD, Seeger K, Henze G, von Stackelberg A, Hagemeier C, Eckert C, KirschnerSchwabe R. Mutations and deletions of the TP53 gene predict nonresponse to treatment and poor outcome in first relapse of childhood acute lymphoblastic leukemia. J Clin Oncol. 2011; 29:3185-93. https://doi.org/10.1200/ JCO.2011.34.8144.

53. Richter-Pechanska P, Kunz JB, Hof J, Zimmermann M, Rausch T, Bandapalli OR, Orlova E, Scapinello G, Sagi JC, Stanulla M, Schrappe M, Cario G, Kirschner-Schwabe R, et al. Identification of a genetically defined ultra-high-risk group in relapsed pediatric T-lymphoblastic leukemia. Blood Cancer J. 2017; 7:e523. https://doi.org/10.1038/bcj.2017.3. 